\title{
Development of The Structure and Construction of Seaweed Farmer's Residence in Bantaeng Regency
}

\author{
Pratiwi Mushar, ${ }^{\mathrm{a}, *}$ Victor Sampebulu', ${ }^{\mathrm{b}}$ \\ a'Laboratory of Material, Structure and Building Construction, Architecture Department, Engineering Faculty, Hasanuddin University. \\ Email: pratiwimushar@unhas.ac.id \\ 'baboratory of Material, Structure and Building Construction, Architecture Department,, Engineering Faculty, Hasanuddin University. \\ Email: victorsampebulu@unhas.ac.id
}

\begin{abstract}
Seaweed farmer is one of the biggest livelihoods of the society in Bantaeng Regency. The problems of seaweed farmer's residence in Bantaeng city (case study) are as follows: First, the excessive utilization of the residence so the hierarchy of the space is not clear. Second, utilizing the structure or construction of the residence as a place of goods storage and as a place for clothes drying simultaneously that can affect the building structure security. Third, the addition of space on the residence without a good planning on the structure and construction of the residence. Fourth, the spatial function for seaweed processing activities built in residential area and inside the residence itself so seaweed industry processing developed in dense, slum, without sanitation and unfit for habitation. The purpose of the research is to analyze the structure and construction of seaweed farmer's residence in Bantaeng Regency from the viewpoints of its spatial organization and function. The data were obtained by the direct survey and field observation where the interview is conducted by using questionnaire. The society aspiration data were obtained by using Focus Group Discussion (FGD) approach. Technical analysis is conducted by using qualitative description. The result of the analysis shows that (1) The space in the growing and developing residence is influenced by some seaweed farmer's activity and that spatial development influences the structure and construction development of stilt house buildings that are structured or overlapping each other. The construction development is conducted independently by the owner of the residence without appropriate or standard basic constructions. (2) The concept of the structure and development of farmer's residence maintains the construction system of Bugis-Makassar stilt house but the procurement of spatial organization is needed by the seaweed farmer.
\end{abstract}

Keywords: Construction; seaweed farmer; seaweed farmer's residential; structure

\section{Introduction}

Seaweed farming is one of the biggest livelihoods of the society in Bantaeng Regency. The problems of seaweed farmer's residence in Bantaeng city (chosen as a target of case study) are summarized as follows:

- The excessive utilization of the residence makes the hierarchy of the spatial unclear.

- The structure or construction of the residence is utilized simultaneously as a place of goods storage and as a place for clothes drying, and this affects security of the building structures. (Figs.1 and 2)

- The addition of space is made to the residence without a good planning in terms of the structure and construction of the residence. (Fig.3)

*Corresponding author. Tel.: +6281355084736

Jalan Perintis Kemerdekaan 4 Lr. 5 No. 2

Makassar, Indonesia, 90245
- The spatial function for seaweed processing is built in residential areas and even in the residence itself, so the seaweed processing is made in dense and slum environment without sanitation and unfit for habitation. (Fig. 4)

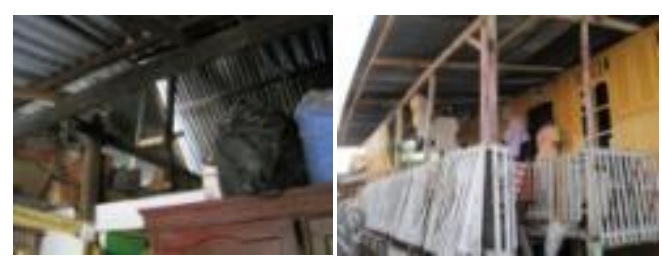

Figure 1. Illustration of utilizing the structure or construction of the residence as a place of goods storage and as a place for clothes drying 


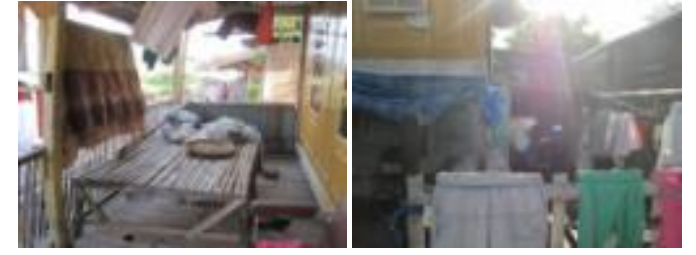

Figure 2. Illustration of the spatial function for seaweed processing activities built in residential areas and in the residence

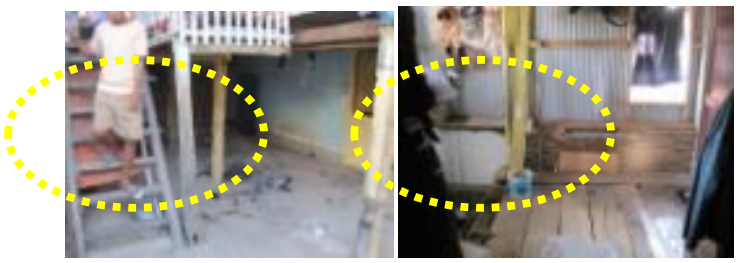

Figure 3. Illustration of the addition of space to the residence without a good planning on the structure and construction of the residence

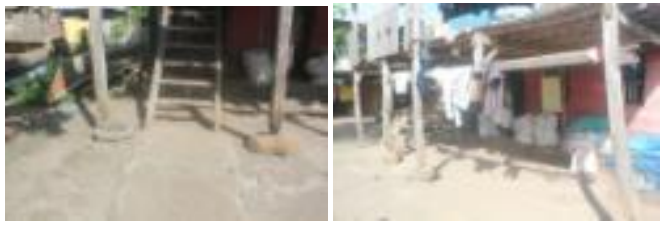

Figure 4. Illustration of the insecure residence construction in Letta village because of the live/dead loads and aged wood material.

The purpose of the research is to analyze the problems of structure and construction of seaweed farmer's residence from the viewpoints of its spatial organization and function. Bantaeng Regency is chosen as a survey area.

The present research refers to a series of previously conducted researches, which are the study on the location development principles of productive residence and processing of community-based seaweed (case study: Watershed of Bantaeng Regency) by Wunas [1] in 2014 and the study on prototypes of productive energy-efficient residence and model of residential area with seaweed processing industry (case study: river bank of Bantaeng Regency) by Wunas et al [2] in 2016. Specifically, it can be emphasized that this research is beneficial to seaweed farmers for them to have safer and more functional residence. Other researches by Wunas [3-7] are referred for more information, and references [8-11] are also useful for general information in methodology and conceptual ideas.

\section{Methodology}

The research was conducted in Bantaeng Regency, specifically in the coastal area of Calendu, Letta village, and Bantaeng sub-district. Data collection was done by direct survey (Table 1). The field observation of seaweed farmer residences was measured in detail and documented, and direct interview was made with seaweed farmer. The society aspiration data were obtained by using Focus Group Discussion (FGD) approach. Data analysis methods used in the research were qualitative descriptive and comparative.

\section{Result and Discussion}

3.1. Analysis of Design, Structure, and Construction of Seaweed Farmer's Residence Reviewed from Its Spatial Orgaization and Function in Bantaeng Regency.

\subsubsection{Roof construction}

The roofs that are used is a saddle and a shield roofs with the construction of simple wooden trestle similar to roof construction in the traditional Bugis-Makassar house. Zinc is used as a roof covering material. (Fig. 5)

Table 1. Residence Plan Types of Seaweed Farmer's Residence

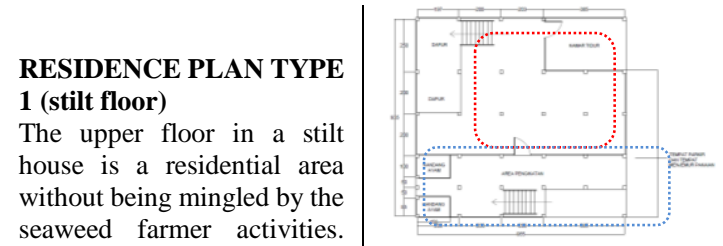
seaweed farmer activities.

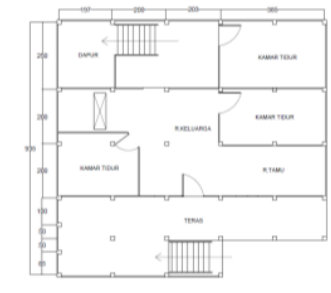

The farmers developed their stilt houses on by utilizing the house basement become residential and seaweed processing functions

\section{RESIDENCE PLAN TYPE} 2 (stilt floor) The upper floor is used only for residential activities such as receiving guests, cooking, relaxing, sleeping, etc.
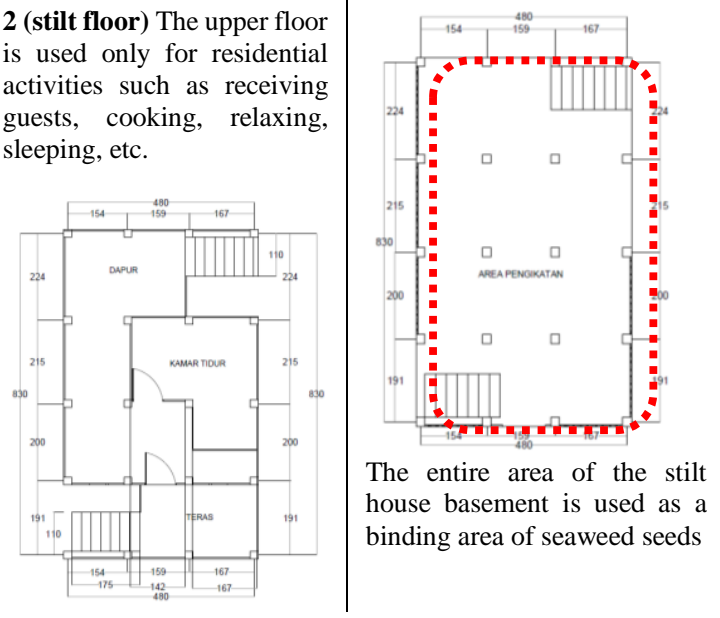

The entire area of the stilt house basement is used as a binding area of seaweed seeds

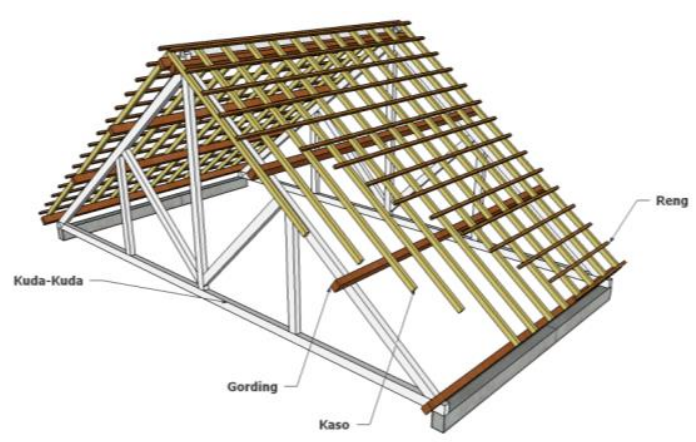

Figure 5. A saddle shape roof can provide an effective wind circulation system when ventilated. 


\subsubsection{Wall-floor construction}

a. $\quad$ Floor (Figs. 6 and 7)

The wall material made of plank is constructed with the tongue and groove construction and the partition material of the room is using plywood.

Construction of skeletal frame wall has several advantages:

- $\quad$ Saving $\pm 50 \%$ of wood building materials.

- Higher stability against buckling.

- High stability to horizontal force by wallcoverings such as multiplex or diagonal wooden plank.
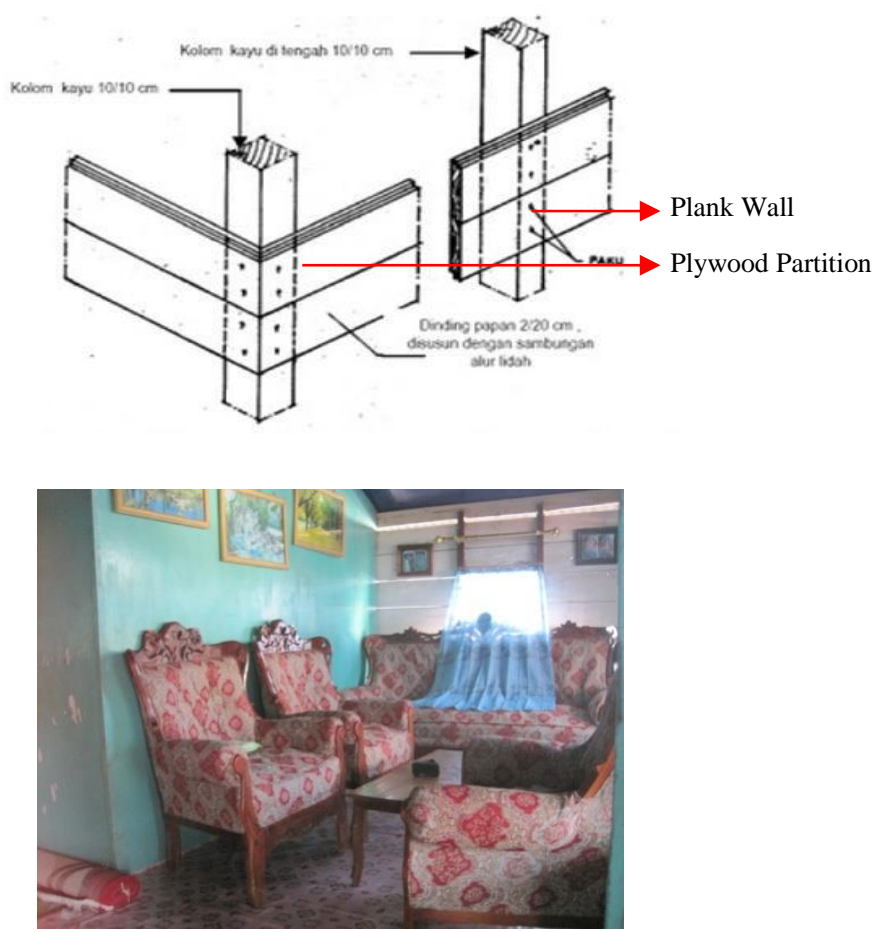

Figure 6. Construction and wall material in seaweed farmer's residence

b. Wall

The floor construction of stilt house is supported/carried by the longitudinal beams or pallangga, then distribute the force to the main beam or pattoddo.

Floor beams are the lowest wooden construction as a floor support or as a support beam, which is usually made of 1 st grade wood that is resistant to termites.

Preservation of low-grade wood does not guarantee resistance to termites. Painting the surrounding floor beams can pose a danger of decay because of all the pores on wood are closed.

\section{c. House Basement Construction}

The house basement consists of several poles that serve as a trestle and tied by a transverse beam (pattoddo) and tied by a longitudinal beam (pallangga). (Fig. 8)
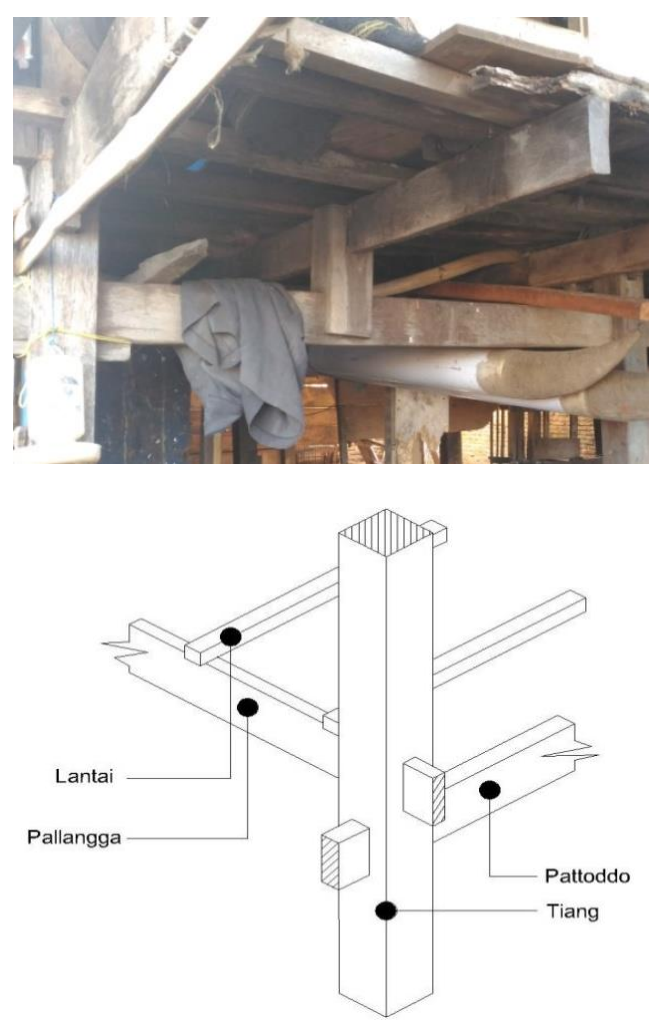

Figure 7. Floor construction in seaweed farmer's residence
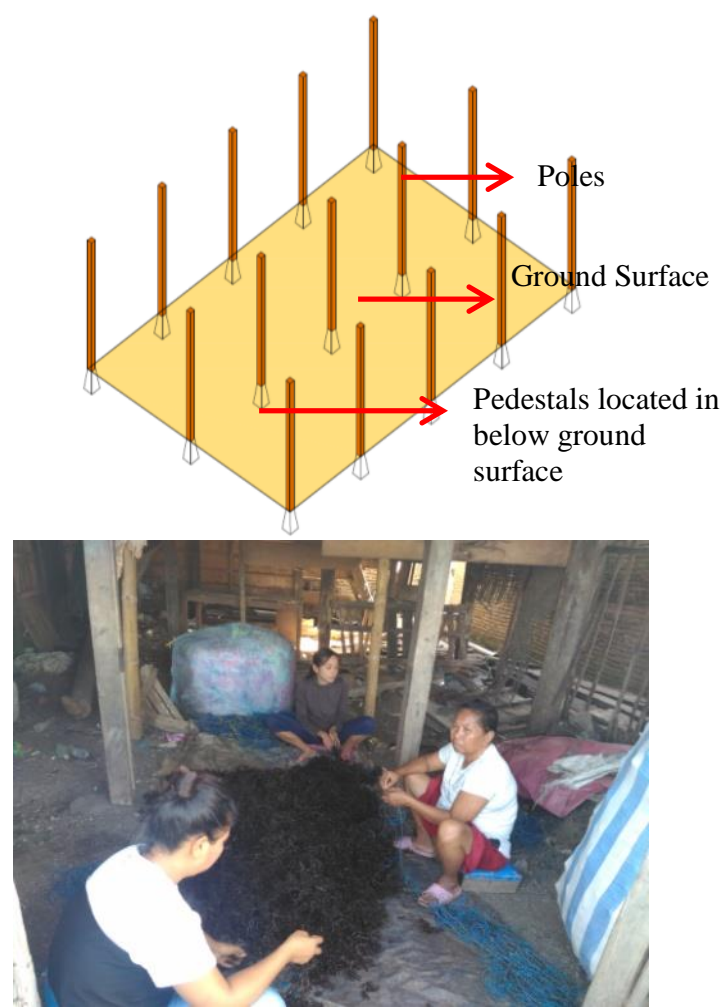

Figure 8. Basement Construction in seaweed farmer's residence

The foundation that is used is a pedestal system. The foundation of the house basement. The poles were made by wood material. 


\subsection{Spatial Organization}

Spatial organization functions to understand how the relation between space is created. (Figs.9 and 10)

With the need of existing standard space, the spatial planning and organizing can be made by conduct zoning, grouping, and circulation studies.

<Function of Spatial Organization>

- Making the house more compact

- The house circulation becomes comfortable
- Space relate to each other is well connected.

- The house appearance becomes more interesting.

- Manufacturing cost can be more efficient

Based on the description in Table 2, the space created is not fully functionalized or utilized by the residents. Living room is very rarely used as well as the terrace because the socialization of seaweed farmer society there is very strong that the interaction between people or individuals with each other happens outside the residence only.

Table 2. Spatial and zone organizations of seaweed farmer's residence

\begin{tabular}{|c|c|c|c|c|}
\hline SHAPE & $\begin{array}{c}\text { Space organization before } \\
\text { development }\end{array}$ & Zone & $\begin{array}{c}\text { Space organization after } \\
\text { development }\end{array}$ & Zone \\
\hline \multicolumn{5}{|l|}{ Type 1} \\
\hline Roof & Not functioned & - & Attic warehouse & In service \\
\hline \multirow[t]{5}{*}{ Main structure } & Terrace & Public & Terrace & Public \\
\hline & Living room & Semi public & Living room & Semi public \\
\hline & Family room & Private & Family room & Private \\
\hline & Bedroom & Private & Bedroom & Private \\
\hline & Kitchen & In service & Warehouse & Private \\
\hline \multirow[t]{8}{*}{ Basement } & Livestock space & Semi private & Bathroom & Private \\
\hline & Water disposal & In service & Kitchen & In service \\
\hline & Courtyards & In service & Toilet & In service \\
\hline & & & Well & In service \\
\hline & & & Parking lot & Semi private \\
\hline & & & Cage & In service \\
\hline & & & Fishing equipment warehouse & In service \\
\hline & & & Courtyards & In service \\
\hline \multicolumn{5}{|l|}{ Type 2} \\
\hline Roof & Not functioned & & Not functioned & \\
\hline \multirow[t]{5}{*}{ Main structure } & Terrace & Public & Terrace & Public \\
\hline & Living room & Semi public & Living room & Semi public \\
\hline & Family room & Private & Family room & Private \\
\hline & Bedroom & Private & Bedroom & Private \\
\hline & Kitchen & In service & Warehouse & In service \\
\hline \multirow[t]{2}{*}{ Basement } & Livestock space & Semi private & Seaweed tying space & Semi private \\
\hline & Water disposal & In service & & $\begin{array}{l}\text { (probably used by } \\
\text { family/relatives) }\end{array}$ \\
\hline
\end{tabular}

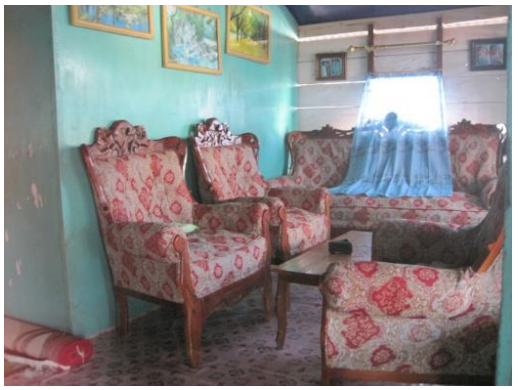

Figure 9. Living room is rarely functioned and filled with furniture that is quite heavy and disproportionate with the space so that it affects the construction of floors (planks) which are sag.

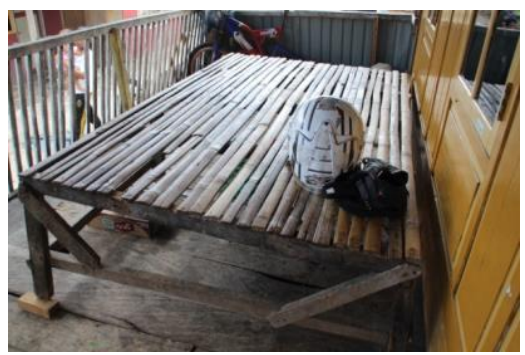

Figure 10. Terrace is used for a short break and place to work
Toilet still less calculated in the spatial planning by the residents. Even the toilet is placed separately from the building. But some houses have built the toilet under a building that has been built permanently.

Construction of residence reviewed from special organization and function is summarized in Table. 3.

\subsection{Analysis of Residence Structure}

Stilt houses have a number of advantages such as:

- Anti Flood

- Safe against wild animals

- Larger Yard

- Resist to Earthquake

- Strong Traditional

- Unique Shape

- Cooler Interior

The disadvantages of the stilt house are that the houses require funds and architecture to make it and the stilt houses require a certain material and slightly different from ordinary house in general. Also, the stilt houses take a fairly long time on the construction process. 


\subsubsection{Residence type}

The design of seaweed farmer's residence in Bantaeng Regency is dominated by traditional stilt house of South Sulawesi (Bugis-Makassar) (Fig. 11). It can be seen from the structure and construction of the houses which consists of:

a. Roof Design (Top)

Top Benua or a triangular house head characterized by tropical buildings in the eastern part of Indonesia. Traditionally, the roof functioned as a place to store crops.

b. Body Design (Middle)

Middle Benua or a rectangular house body that functions as a place to perform daily activities of the residents

c. Basement Design (Bottom)

Bottom Benua or the house basement. It is described as the foot of the house and serves as a place to rest and socialize with neighbors.

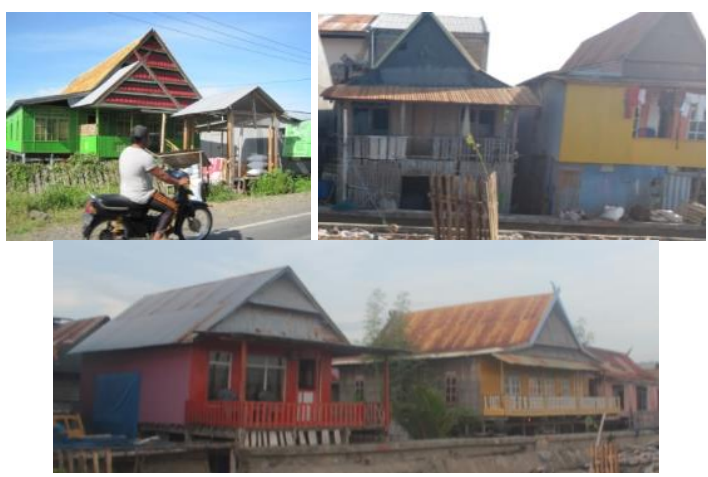

Figure 11. The design of Bugis Makassar stilt house dominated the design of seaweed farmer's residence in Bantaeng Regency

\subsubsection{Dimension}

Generally, the width of the stilt house is $\pm 45 \mathrm{~m} 2-90 \mathrm{~m} 2$, with dimensions of type $\pm 5 \mathrm{~m} \times 9 \mathrm{~m}$, and type $\pm 10 \mathrm{~m} \times 9 \mathrm{~m}$. The type of space located on the stilt floor is a terrace that functions as a semi-public living room, bedroom, and kitchen. Service facilities such as laundry room and toilet are located outside of the stilt building. Multiple of building module (length between pole to pole) is 2 meters. The pole dimension is dominated by size of $25 \mathrm{~cm} \times 25 \mathrm{~cm}$. (Fig.12)

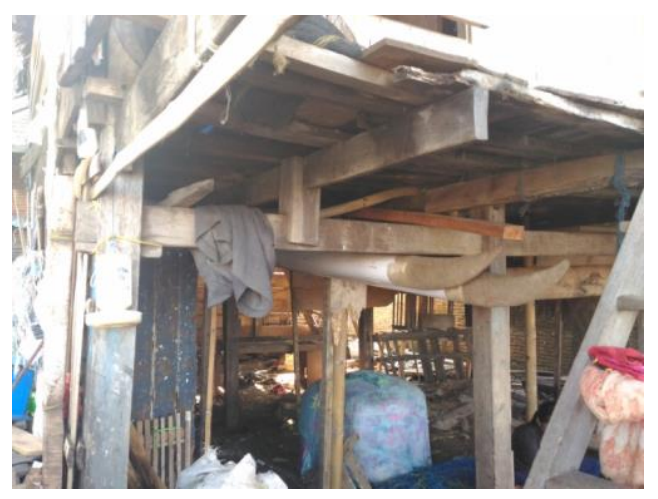

Figure 12. Illustration of stilt house poles

\subsubsection{Building material}

Building materials are any materials used for construction purposes. Many natural materials, such as clay, sand, wood and stones, even twigs and leaves have been used to build buildings. Aside from natural ingredients, artificial products are widely used and some of them are less synthetic. Manufacture of building materials is established in many countries and the use of such materials is usually divided into certain specialized trades, such as carpentry, piping, roofing and insulation work. These references relate to human habitation and structures including houses.

a. Roof Material (Fig. 13)

Roofing material used in stilt house is dominated by zinc. Construction of trestle is made of wooden beams. While the ceiling material only use tarpaulin to reduce the heat effect from the zinc.

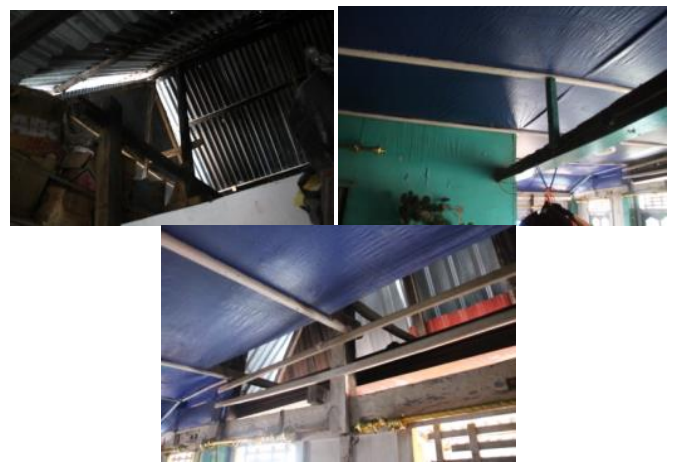

Figure 13 Materials in the roof

b. Wall Material (Fig. 14)

The wall used in the stilt house is a combination of planks and plywood as partitions. While in the basement wall, some have used a brick in combination with plywood as a space divider.

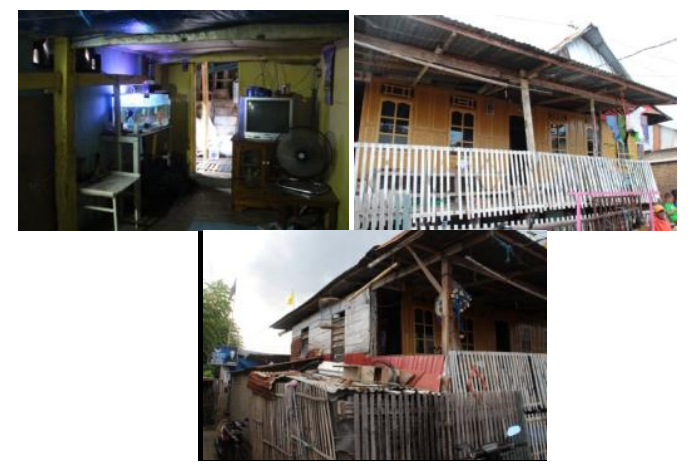

Figure 14. Materials in the wall

c. Floor and Basement Material (Fig. 15)

The stilt house basement has been built due to the increasing need for space. It is influenced by the growing number of residents of the house or the desire of residents to have a wider space such as kitchens and bedrooms. 


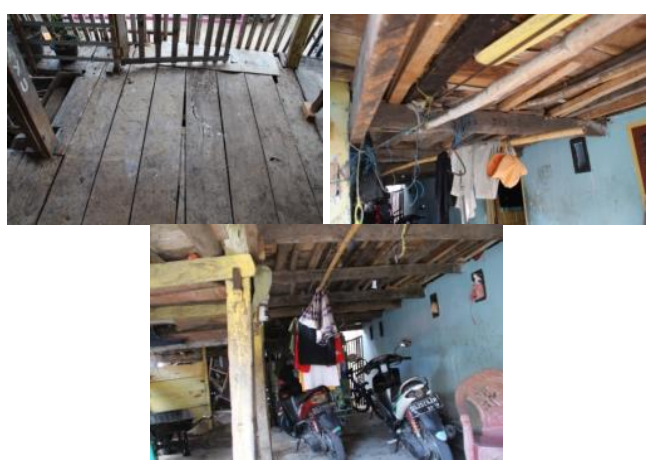

Figure 15. Materials in floor and basement

Table 3 Construction of residence reviewed from spatial organization and function

\begin{tabular}{|c|c|}
\hline \multicolumn{2}{|r|}{ Plan Type 1} \\
\hline Top (Roof) & $\begin{array}{l}\text { it can be seen the structure / construction } \\
\text { of the roof of the house (trestle) used by } \\
\text { the residents as a storage space of goods } \\
\text { by adding another construction (wood) } \\
\text { and attached it with straps on the trestle } \\
\text { to sustain or to store goods. It is done } \\
\text { without consideration of the roof } \\
\text { construction safety. }\end{array}$ \\
\hline $\begin{array}{l}\text { Middle } \\
\text { Floor) }\end{array}$ & $\begin{array}{l}\text { teracce/lego-lego,living room, bed room, } \\
\text { family room, and warehouse. }\end{array}$ \\
\hline
\end{tabular}

Teracce/lego-lego is generally used for gathering or receiving guests, but almost all houses in this area utilize the terrace as a working area of seaweed farmers. Changes in the function of this space does not affect the building construction.

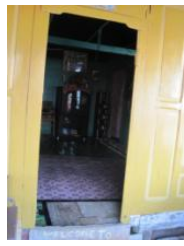

The main access to the residence (Only one access)

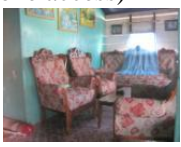

Living room is made but the furniture used in it is not too functioned.

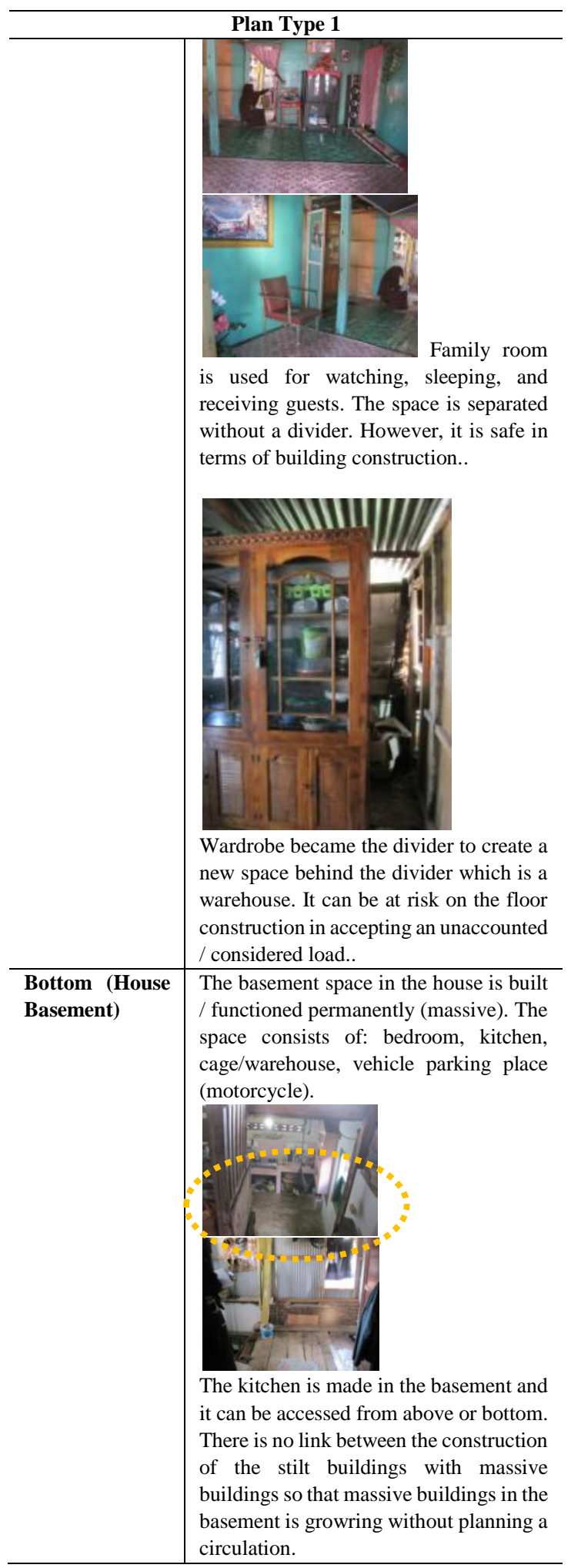




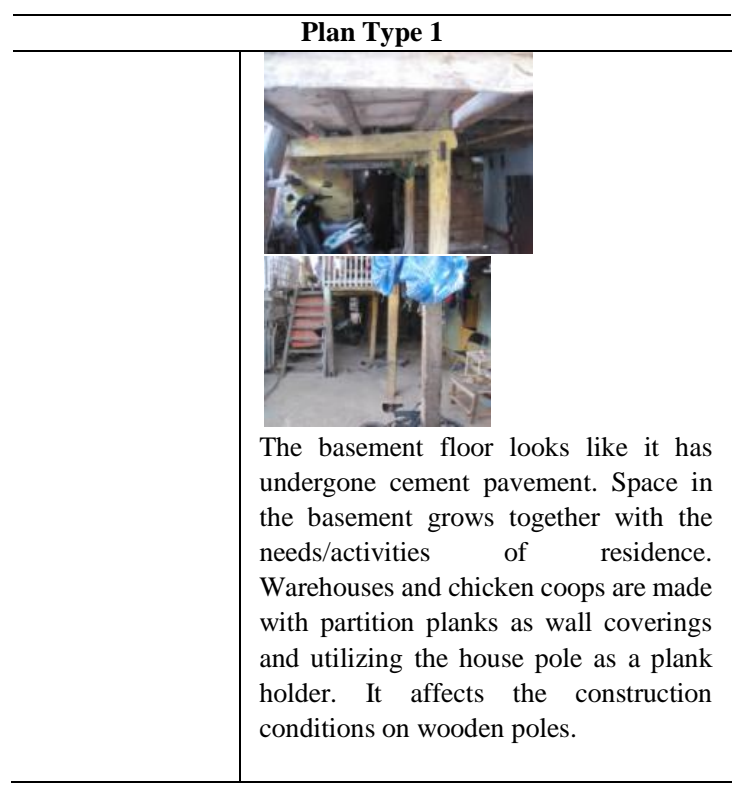

\subsection{Development Concept of Structure and Construction of Seaweed Farmer's in Bantaeng Regency}

The design of seaweed farmer's residence in Bantaeng Regency is developed based on the society needs and activities. Residence development is conducted independently by the residents without basic knowledge of building security and safety. Based on the above analysis, development concept of the structure and construction of seaweed farmer's residence is proposed as follows (Fig. 16):

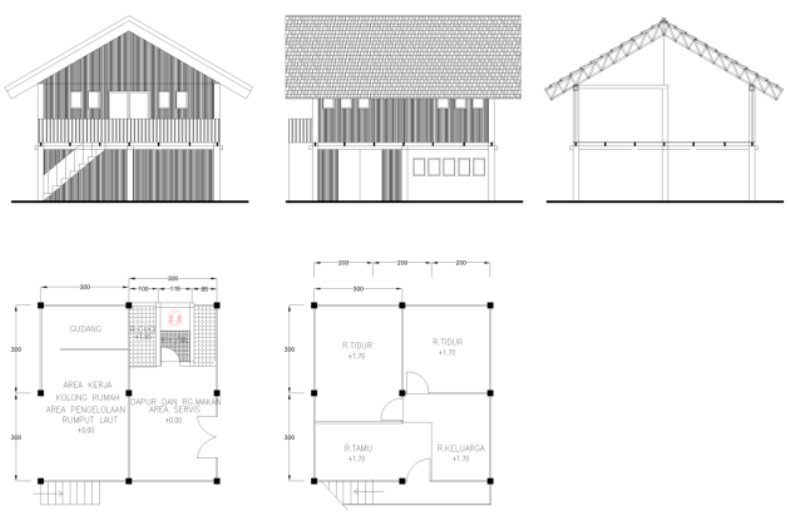

Figure 16. Illustration of development concept of structure and construction of seaweed farmer stilt house reviewed by spatial organization and function

\section{Conclusion}

There have been tendencies in seaweed farming residence that additional space is extended without structural and functional consideration in the residence and this unfavorable extension has influenced negatively on some seaweed farmer activities and quality of life. For improving such working and living situations, survey was made to measure the structure of seaweed farmers' stilt houses and to study spatial organization and building materials. Based on such collected data, analysis was made to improve the current problems, and the concept of structure and construction was proposed for a new type of seaweed farmer's house. It is hoped that the new concept of the structure and construction for seaweed farmer's stilt house with basement can improve both efficiency of the work and quality of farmer's life. Particularly, the addition of space with mezzanine concept to create a space on the roof may create a storage place of goods and mini warehouse.

\section{References}

[1]. Wunas, dkk. 2014. Prinsip-prinsip pengembangan lokasi perumahan produktif dan industry pengolahan rumput laut berbasis komunitas (kasus DAS Kabupaten Bantaeng). Unhas, penelitian hibah kompetensi.

[2]. Venny Veronica Natalia, Wunas, Shirly. 2016. Housing development: sign and symptoms in middle city of Indonesia. ELSEVIER, Procedia: Social and behavioral sciences, 227(2016)278-285, akses Science Direct.

[3]. Wunas, dkk, 2013. Pengembangan sentra produksi rumput laut melalui dukungan jaringan transportasi di Kabupaten Bantaeng, kerjasama Litbang perhubungan.

[4]. Wunas, S. 2013. Model perluasan bangunan swadaya sebagai pendukung fungsi hunian dan usaha berbasis ramah lingkungan, dipresentasikan dalam seminar Nasional temu ilmiah IPLBI.

[5]. Wunas, S. 2013. Housing on waterfront landuse conflict in City of Kolaka. On Seminar international architecture in urbanize maritime culture.

[6]. Wunas, and Veronica. 2013. Traditional sailing and local economic development in rural area of Sulawesi Island. Seminar Internasional of FSTPT Solo.

[7]. Wunas, S. 2008. Pengembangan perumahan swadaya di wilayah pesisir Sulawesi Selatan (Kasus Kabupaten Takalar), kerjasama Kemenpera.

[8]. Frick Heinz. 2006. Seri Eko-Arsitektur 2, Arsitektur Ekologis, Konsep arsitektur ekologis di iklim tropis, penghijauan kota dan kota ekologis, serta energy terbarukan. Kanisius Soegijapranata University Press.

[9]. Isfa sastrawati. 2009. Pengembangan rumah panggung swadaya tahan bencana melalui pemberdayaan masyarakat di kawasan pesisir sulawesi selatan. Penelitian hibah kompetitif penelitian sesuai prioritas nasional (Hibah Penelitian Strategis Nasional).

[10]. Turner,J.F.C. 1976. Housing By People, Towards autonomy in buiding environments, Marion Boyars London.

[11]. Van Lengen Johan, The Barefoot Architect. A Handbook for Green Building. Shelter Publications. Bolinas, California. USA. 